\title{
DOES THE INCLUSION OF WOMEN ON THE BOARD ADD PROFIT AND VALUE ADDED TO FIRMS? ${ }^{1}$
}

\author{
Kafkas University \\ Economics and Administrative \\ Sciences Faculty \\ KAUJEASF \\ Article Submission Date: 26.08.2021 \\ Accepted Date: 18.10 .2021
}

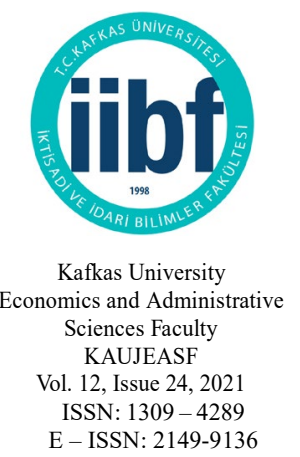

\section{Tuncer YILMAZ}

Lecturer, Dr.

Kafkas University

Vocational School of Susuz, Kars, Turkey

yilmaz-tuncer@hotmail.com

ORCID ID: 0000-0001-8956-5814

\author{
Aliriza AĞ \\ Asst. Prof. Dr. \\ Bayburt University \\ Faculty of Economics and \\ Administrative Sciences \\ Bayburt, Turkey \\ alirizaag@bayburt.edu.tr \\ ORCID ID: 0000-0001-5345-6245
}

\section{Yunus ZENGIN}

Assoc. Prof. Dr.

Kafkas University

Faculty of Economics and

Administrative Sciences

Kars, Turkey

yunuszengin@kafkas.edu.tr

ORCID ID: 0000-0001-8381-6918

\section{ABSTRACTI Based on the}

idea that the majority of family companies and the dominance of patriarchy in the social structure in Turkey may reduce the effectiveness of female managers in company management, this study aims to examine the effect of female managers on firm performance in Borsa Istanbul (BIST) companies. We limited our study to 126 manufacturing companies that were continuously traded in the BIST in the 20102017 periods. In general, the following results were obtained in the multiple regression analyzes. The ratio of women in the board of directors and the presence of at least 1 woman in the board of directors were not found to have a significant effect on performance criteria. While the effect of having 2 or more women in the board of directors on ROE and having 3 or more women on EVA/TA was significant, the effects on other performance criteria were not found to be significant.

Keywords: Female director, board of directors, profit, value added.

Jel codes: G30, G34, J16

Scope: Business Administration

Type: Research

DOI: 10.36543/kauiibfd.2021.032

Cite this Paper: Y1lmaz, T., A $\breve{g}$, A. \& Zengin, Y. (2021). Does the inclusion of women on the board add profit and value added to firms? KAUJEASF, 12(24), 781-809.

\footnotetext{
${ }^{1}$ Compliance with the ethical rules of the relevant study has been declared.
} 


\title{
YÖNETIM KURULUNDA \\ KADINLARIN OLMASI FİRMALARA \\ KÂR VE KATMA DEĞER \\ KATIYORMU?
}

\begin{abstract}
Kafkas Universitesi İktisadi ve İdari Bilimle Fakültesi KAÜIİBFD

Cilt, 12, Say1 24, 2021

ISSN: $1309-4289$

Makale Gönderim Tarihi: 26.08.2021

Yayına Kabul Tarihi: 18.10.2021

E - ISSN: 2149-9136

Tuncer YILMAZ

Öğr. Gör. Dr.

Kafkas Üniversitesi

Susuz Meslek Yüksekokulu,

Kars, Türkiye

yilmaz-tuncer@hotmail.com

ORCID ID: 0000-0001-8956-5814

\author{
Aliriza A $\breve{G}$ \\ Dr. Öğr. Üyesi \\ Bayburt Üniversitesi \\ İktisadi ve İdari Bilimler Fakültesi, \\ Bayburt, Türkiye \\ alirizaag@bayburt.edu.tr
}

ORCID ID: 0000-0001-5345-6245

\section{Yunus ZENGIN}

Doç. Dr.

Kafkas Üniversitesi

ÖZ| Türkiye'de aile şirketlerinin çoğunlukta olmasının ve toplum yapısında ataerkil yapının hâkim olmasının, şirket yönetimlerindeki kadın yöneticilerin etkinliğini azaltabileceği düşüncesinden yola çıkarak bu çalışmada, Borsa İstanbul (BIST) firmalarında kadın yöneticilerin firma performansı üzerindeki etkisini incelemek amaçlanmıştır. 2010-2017 döneminde BIST'te kesintisiz olarak işlem gören 126 imalat firmasını alarak çalışmamızı sınırlandırdık. Yapılan çoklu regresyon analizlerinde genel olarak şu sonuçlar elde edilmiştir. Yönetim kurulundaki kadın oranı ile yönetim kurulunda en az 1 kadın olmasının performans ölçütleri üzerinde etkisi anlamlı bulunmamıştır. Yönetim kurulunda 2 ve daha fazla kadın olmasinın ROE, 3 ve daha fazla kadın bulunmasının EVA/TA üzerindeki etkisi anlamlı iken, diğer performans ölçütleri üzerindeki etkileri ise anlamlı bulunmamıştır.
\end{abstract}

İktisadi ve İdari Bilimler Fakültesi

Kars, Türkiye

yunuszengin@kafkas.edu.tr

ORCID ID: 0000-0001-8381-6918
Anahtar Kelimeler: Kadın yönetici, yönetim kurulu, kâr, katma değer.

JEL Kodu: G30, G34, J16

Alan: İşletme

Türü: Araştırma 


\section{INTRODUCTION}

The participation of women employees in the labor force, which is an important factor in sustainable economic development, is of great importance for the development of both microeconomic and macroeconomic policies of countries. Despite the importance of women's employment, it is seen that the place of women in the economic structure in our country is lower than that of men. The incompatibility of the qualitative skills of women, especially in the process of entering the working life, and the conditions of entry to the labor market can be counted among the important reasons why women are lower than men in total employment in Turkey. In addition, factors such as the incompatibility between two different lifestyles in the migration from the village to the city, the level of education, the high number of children, and the layoffs in times of economic crisis play a retarding role in the change of this process.

However, it is thought that the positive policies pursued by both public and private sector representatives towards women's employment and the decrease in the "role difference" thoughts between gender discrimination in the country are effective in the increase in the number of women in working life day by day.

According to the "Gender Gap 2017 Report" of the World Economic Forum, it is stated that there is a $32 \%$ difference between women and men in terms of both basic needs, opportunities encountered and the resulting gains. Although this gap has largely closed in basic areas such as education and health, it is seen that the gap continues especially in the areas of participation in the economic process and influence in political decisions (Ministry of Development, 2018: 1). Factors such as eliminating the sectorial distinction between genders in employment, developing central government social policies and local government practices to increase women's employment, increasing incentives to increase women's entrepreneurship, and providing necessary trainings to improve their competencies in the labor market play a major role in reducing this gap.

Women employees are individuals who cannot be at the forefront of the society but have a significant impact on the development and progress of the society. The more productive and active women play a role in society, the more the social development process will increase. For this reason, the participation of women in economic life is of great importance in terms of the emancipation of labor force in social and economic development. In addition, this role undertaken by women will also enable them to change their social status by giving them a separate identity in the society (Karabiy1k, 2015: 240).

When women are faced with the desire to contribute to the economic situation of the family and to have a say in the administrative sense by destroying the traditional patterns existing in the society, by not accepting the role of mother 
or wife in the social context, they have to overcome many individual and social obstacles (Karatepe and Aribaş, 2015: 8). Such obstacles, which are evaluated within the scope of gender and role inequalities, are frequently encountered in business life as well as in daily life. There are obstacles that prevent them from taking part in business life and even being promoted, which are expressed as "glass ceiling syndrome" in the field literature, especially for women in business life.

Glass ceiling is a syndrome that prevents women from being preferred and progressed in managerial areas, especially when compared to the total number of women in the workforce (Mordi et al., 2011; Kolade and Kehinde, 2013: 79). They are invisible artificial barriers that prevent women from reaching higher positions within organizations. This is why women must overcome isolation, gender stereotypes and performance pressures in order to be a successful manager (Akpinar-Sposito, 2013: 489). The fact that companies cannot hold senior management positions due to these obstacles in front of women causes other problems in terms of their representation in company boards of directors. The fact that the insufficient number of female managers in the boards of directors, which constitutes the managerial decision mechanism of the companies, brings "the glass ceiling syndrome" to mind (Şahin et al., 2018: 1149).

Despite the efforts made in democratization movements in our country, it is seen that the position of women in the processes of authority, responsibility and participation in decisions is not at the desired level. This shows us that women do not have sufficient administrative and political effectiveness (Karatepe and Arıbaş, 2015: 9). However, we can say that various studies and developments have been experienced in our country, especially since 1995, in order to adapt to the changing new world order (Tunç et al., 2015: 12). Foremost among these, the elimination of reservations made by the "Convention on the Elimination of All Forms of Discrimination Against Women" (CEDAV) adopted by the United Nations in 1979, inclusion in the 1995 Beijing Declaration and action plans, the establishment of the Ministry of Family and Social Policies in 2011 and the fact that its managers were selected from women are among the positive developments towards this process. In addition, researching the effectiveness of women executives in the boards of companies in the strategic and operational decisions of companies in recent studies (Carter et al., 2003; Arosa et al., 2010; Lanis \& Richardson, 2011; Ertimur et al., 2010) has also enabled the elimination of the legal deficiency in this issue. Despite the adoption of a moderate transition process to the legislation including the corporate governance codes that have been put into practice since 2003, the fact that many principles were not followed in 
the reports published on the results necessitated the need for legal arrangements regarding this process. In this context, it can be stated that the change in the "Corporate Governance Principles" communiqué in Turkey in 2012 and the statement of "at least one female member in the board of directors", and its inclusion as a recommendation in the Turkish Commercial Code (Şahin et al., 2018: 1148) allow women to overcome the glass ceiling syndrome they have experienced to some extent. Corporate governance can be expressed as a managerial process that determines the management of companies and their shareholders, the board of directors, the relations between managers and other stakeholders who are in relationship and expectation, and includes the rules for protecting the rights of all the elements in the company, especially the shareholders (Meydan and Basım, 2007: 49). In other words, corporate governance means the rules that regulate the relationship between company management and shareholders and stakeholders (Aktan, 2013: 152).

The corporate scandals encountered around the world in recent years have turned all the attention to the corporate governance principles, which constitute the basic content of the management, and specifically to the company's board of directors (Arslantaş, 2012: 2). The boards of directors are among the most important corporate governance mechanisms that will ensure that company executives behave in a way that takes into account the interests of the shareholders holding company shares (Atılgan, 2017: 316).

Research on the effectiveness of boards considering the stakeholder perspective and based on classical corporate governance theories, argues that board members and managers of companies have wider responsibilities besides increasing shareholder share value and protecting the interests of the owners (De Andres et al., 2005; Kouaib et al., 2020). Financial scandals and moral losses in recent years have put corporate boards under increasing pressure to recognize the need for monitoring and to respond to societal obligations. In this sense, it is emphasized that the duties of the boards of directors are no longer limited to maximizing shareholder value, but also to address the increasing concerns about sustainable performance practices in institutions (Buallay et al., 2020:4; Rao and Tilt, 2020: 63). In this context, it is of particular importance for the implementation of a successful corporate governance to design the structures of the board of directors that will align the interests of the shareholders and stakeholders of the companies with each other; because in the studies in the literature on the subject, the structure and characteristics of the board of directors come to the fore as factors affecting company performance (Anderson and Reeb, 2004: 221). 
Modern boards of directors have to monitor and oversee the performance and activities of top management in order to best protect and evaluate the interests of the company's shareholders (O'Connell and Cramer, 2010: 387). In their audit assignment, boards use their time and resources to monitor firm performance and the behavior of senior managers (Martinez and Alvarez, 2020: 1252). In addition, the boards of directors also undertake duties such as developing company strategy, implementing these strategies in the best way, and establishing solid relations with the external environment. When the contents of these duties are analyzed, it can be seen that the boards of directors have a direct impact on the financial and value performances of the companies (Karayel and Doğan, 2014: 76). The fact that various scandals have occurred in certain periods in the boards that have undertaken such important tasks, as stated above, has led to the criticism of their structure, features and their effects on company performance (Hsu \& Wu, 2014) and questioning its homogeneity. On the other hand, according to the estimation results of the model in the study conducted by Erhardt et al. (2003) for 127 large companies in the USA in 1993, it was determined that the performance of the companies increased and a positive effect emerged as a result of the increase in the diversity in the boards of directors of the companies (Doğan, 2018:134). It is seen that women's participation in company management is effective in terms of motivation and role model, as well as providing performance and economic contributions. It should not be forgotten that they can set an example for other women by being a role model with their knowledge and experience, creating a friendly atmosphere, helping to increase the image and reputation of the company, and taking place in the senior management and even on the board of directors (Arıoglu, 2014: 19).

The low representation of women in the board of directors has brought about certain discussions. Recent studies reveal that gender diversity in boards of directors has a positive effect on the financial performance of companies. In the study of Carter et al. (2010: 399) it is argued that the increase in gender diversity in the board of directors will increase the independent behavior of the board. The main reason is that female board members tend to ask questions that male members cannot (Carter et al., 2003: 37). In addition, the fact that women members create different perspectives due to their degree of preparation for board meetings, their professional profiles and collaborative excellence will ensure a better quality of discussions in the board (Liu et al., 2014: 169). In the genderdiverse board of directors, female members also add a different perspective to the decision-making process, helping to understand the complexities in the business environment. They can contribute positively to the value of the company by improving the image of the company and therefore the behavior of the customers 
and the performance of the company (Smith et al. 2006; Campbell and Vera, 2010: 43). Since gender diversity on the board is seen as supporting family life, empowering women and advancing flexible working arrangements, it will also help the firm gain positive social acceptance (Francoeur et al., 2008). Women's ability to build relationships (Dargnies, 2012), their ability to make the firm important to female customers and the workforce (Liu et al., 2014), their expertise in human resources and advertising (Balasubramanian and Anand, 2013) can make female board members an invaluable asset for companies (Chauhan and Dey, 2017: 26).

Studies on the number of women on the board of directors, company performance and the added value it produces are based on two theories. The first of these theories is the agency theory and the other is the resource dependency theory (Jermias and Gani, 2014: 137; Chauhan and Dey, 2017: 26). The main element in agency theory is based on balance. Accordingly, there must be a balance between the independent members of the board and the non-independent members. Therefore, it is argued that since the external and independent members will not be under the influence of the chairman of the board of directors and other members, it will enable them to monitor senior managers and their activities more effectively, and this will positively affect the company's performance and market value (Shoham et al., 2020: 2; Jermias and Gani, 2014: 137).

According to resource dependency theory, the main goal of organizations is to maintain their existence. The fulfillment of this aim can only be achieved by providing a competitive advantage that can cope with the environment, creating and developing new resources and capabilities suitable for the ever-changing conditions of competition and choosing strategies to obtain appropriate resources (Çalışkan, 2017: 225). In addition, the theory states that the organization is not only a passive social structure that has to adapt to its environment, but also a social structure that affects its environment with the moves it makes to reach the resources it needs in order to survive (At1lgan, 2017:319). Therefore, it is argued that one of the important functions of the company's board of directors is to provide critical resources such as advice and consultancy to increase the legitimacy of the company (Wang et al., 2020: 3). The inclusion of independent members in the structure of the board of directors will be beneficial for establishing external links with the company, providing information communication, and providing resources that provide support in different subjects and fields. For this reason, it is argued that the board of directors can work more independently by increasing diversity in the board of directors (Ocak, 2013:109). Resource dependency theory, with a similar idea to the agency theory, argues that the number of independent members in the company's board of 
directors is high, and argues that this will make a positive contribution especially in relations with actors outside the company (At1lgan, 2017:319). Another feature of the resource dependency theory is that the diversity in the company's board of directors will facilitate access to critical resources that are important for the company, especially in obtaining resources from the external environment, and will positively affect the financial performance and added value of the company by reducing transaction costs and environmental uncertainties (Hillman et al., 2000: 237-238).

As stated above, in addition to the contributions of gender diversity boards to company value and financial performance, empirical evidence based on agency theory also shows that gender diversity in the board of directors has a positive, negative or insignificant effect on firm performance and market value (Adams and Ferreira, 2009; Carter et al., 2010; Chapple and Humphrey, 2014; Talavera et al., 2018). In addition, scientists state that the excess of gender diversity in the board of directors can lead to possible conflicts in board meetings, which may have negative effects on board compliance, thus hindering the performance and competitive advantage of companies (Jurkus et al., 2011; Post and Byron, 2015; Triana et al., 2014). In particular, not allowing women on some boards the power they need to make effective decisions can lead to poor performance. Thus, diversity is a double-edged sword that can hinder or enhance strategic change and performance (Tasheva and Hillman, 2019: 760). Although there are such opinions in the literature, including gender diversity in the board of directors, that is, the number of female members being in equal balance with the number of male members, will allow the formation of a more balanced board structure and increase the independence of the board of directors. This will cause the decisions to be taken in the board of directors not to be taken on behalf of any person or group (Doğan, 2018: 133).

In a rapidly globalizing world, the management function becomes even more difficult and complex when companies turn to new business areas or markets outside of their core business or existing markets. The structure, size and composition of the company's board of directors may vary depending on the company, sector and country, both due to the legal obligations that bind the company management and some reasons originating from the companies. In this context, it is natural to expect the quality, quantity and gender distribution of the company's boards of directors to have a positive or negative impact on their financial performance; because it has extensively studied the composition of the boards of directors elected by the company's shareholders and the effects of this composition on firm performance (Özen and Yılmaz, 2016: 456). 
The survival of companies operating in accordance with free market economy conditions is closely related to maximizing financial criteria such as profitability, liquidity, growth, added value and firm value. High financial performance increases the interest of both investors and relevant stakeholders in the company (Özen and Yilmaz, 2016: 456). In this context, financial performance indicators are one of the most important criteria that managers, stakeholders, investors, analysts or academic researchers use when determining company performance. In addition, financial performance criteria are among the important determinants in order to compare both the position of the company in the sector and other companies on the basis of common data (Aslantaş and Y1lmaz, 2020: 330).

In this study, which we have conducted based on the above ideas about the structure of the board of directors, we examined the data of 126 companies by applying multiple regression analysis method to seek an answer to the question of whether the distribution of women in the board of directors of companies in the manufacturing sector, which are members of BIST, has an effect on firm performance. Both profit-oriented and value-oriented measures were used as financial performance variables. ROE (Return on Equity) and ROA (Return on Assets) were taken as profit-oriented variables, while MVA (Market Value Added) and EVA (Economic Value Added) were taken as value-added variables.

\section{LITERATURE REVIEW}

When the domestic and international literature is examined, the effect of diversity in the company's board of directors and female managers on company performance has been evaluated in terms of various criteria. These criteria are as follows:

In their study, Farrell and Hersch (2005) examined the effect of diversity in the board of directors of companies and the effect of female managers on the corporate management and financial performance of businesses. As a result of the literature review they conducted for this purpose, Farrell and Hersch observed that female managers have many positive characteristics in terms of value judgment, tendency towards risks and decision-making compared to their male colleagues, and that they tend to serve on the boards of companies with better performance. Adams and Ferreira (2009) examined the effect of female managers on the financial performance of firms in the study they conducted in companies operating in various sectors in the USA. As a result of their analysis, it was determined that there is a positive relationship between gender diversity and profitability. However, they stated that the fact that women are on the board of directors has a significant impact on the value of the firm. 
Wang and Clift (2009) examined the relationship between gender diversity, the percentage of women on the board of directors, and the financial performance of firms, using various data from the top 500 companies operating in Australia. They found that large firms tend to have relatively more female managers and that gender diversity does not have a significant effect on firm performance. Darmadi (2010) examined the relationship between gender diversity in the board of directors and financial performance by using 2010 data of companies traded on the Indonesian stock exchange. According to the findings obtained from the analyzes, a positive relationship was determined between the ratio of female members in the board of directors and profitability. In their study, Julizaerma and Sori (2012) analyzed the relationship between gender diversity in the board of directors and firm performance by using various data of companies operating in Malaysia for the period 2008-2009. As a result of the analysis, it was revealed that there is a positive relationship between gender diversity and firm performance and profitability.

Ocak (2013) analyzed the relationship between the ratio of women in company management and their financial performance, using the data of 101 companies operating in Turkey for the period 2008-2012. According to the research findings, it was determined that ROA, as an indicator of financial performance, increased as the proportion of women in the company's board of directors increased. On the other hand, a negative relationship was observed between the fact that the $\mathrm{CEO} / \mathrm{General}$ manager of the company is female and ROA as an indicator of financial performance. Karayel and Doğan (2014) examined the relationship between gender diversity in the board of directors and financial performance by using the data of companies that are consistently included in the BIST 100 index during the 2009-2012 period. According to the results of the statistical analyzes, there was no significant relationship between the ratio of women in the company's board of directors and ROE and Tobin's q.

Low et al. (2015) examined the effect of female ratio on the profitability of the board of directors of 5,503 companies operating in Hong Kong, South Korea, Malaysia and Singapore. After the analysis of the researchers, it has been determined that female managers have a positive effect on firm profitability. Another finding of the study is that the effect of female managers on financial performance is higher, especially in countries where women's labor force participation is limited, while it is lower in other countries. Garcia et al. (2015) analyzed the effect of board diversity on financial performance in banks in terms of gender and nationality factors. They analyzed the 2004-2010 data of 159 banks from 9 different countries, including Canada, France, Germany, Italy, the Netherlands, Spain, Sweden, the UK, and the USA. According to the results of 
the research, it has been determined that gender diversity has a positive effect on the financial performance of banks, while national diversity has a negative effect on financial performance.

Otluoglu et al. (2016) examined the relationship between gender diversity and financial performance in the board of directors of 49 companies included in the BIST 100 index during the 2010-2015 period. As a result of the analysis, it was seen that the presence of female members in the board of directors has a positive role on ROE and Tobin's q, and the proportion of women in the board has a positive role on ROA and cash flow. Chauhan and Dey (2017) examined the effect of female managers (female ratio, having at least 1 woman, 2 or more women) on firm performance in 3.000 companies operating in both the National Stock Exchange of India and the Bombay Stock Exchange during 2002-2014. In the study, it was concluded that female managers do not make a significant contribution to the financial performance of the companies.

Wiengarten et al. (2017) examined the impact of personal characteristics of those appointed as corporate sustainability managers on financial performance. In the study, profitability ratios of 123 companies were analyzed with various variables covering the 2004-2012 period. As a result of the analysis, it has been determined that the managers related to corporate sustainability have a positive effect on the profitability of the company. Another finding obtained in the study is that there is a positive relationship between the competence of female managers and financial performance, especially in corporate sustainability. In the study of Attlgan (2017), the relationship between the number of board members, the ratio of independent board members, the ratio of female members in the board of directors and financial performance were examined by using data from the period 2011-2016 of 293 firms traded in BIST. As a result of the analysis, it has been revealed that there is a negative relationship between the ratio of female members in the board of directors and financial performance.

Conyon and $\mathrm{He}$ (2017) tested the relationship between firm performance and gender diversity on the board of directors using data from more than 3,000 US firms for the period 2007-2014. According to the analysis findings, it was understood that the fact that women are in the board of directors and their percentage in the board affect the financial performance positively. It has been determined that the effect of gender diversity in the board of directors on market and accounting performance is heterogeneous. It has been determined that female managers have a stronger effect in companies with high financial performance. Ghosh and Ansari (2018) examined the relationship between board size, gender diversity, and financial performance using various data from 1,263 cooperative banks operating in India for 2012. As a result of the analyzes made, it has been 
determined that the various characteristics of the board of directors do not affect the financial performance; however, the gender diversity in the board of directors partially contributes to the financial performance. In their study, Green and Homroy (2018) examined the various characteristics of the board of directors of 177 companies operating in Europe and the effect of female managers on financial performance. In their analysis, it was revealed that the gender information of the children of the CEOs of the companies was taken as a factor in the appointment of women to the company management, the participation of female managers in the board of directors had a positive effect on financial performance, and this situation had a positive effect on the profitability of the company.

Owen and Temesvary (2018) statistically tested the relationship between financial performance and gender diversity in the boards of directors using data from 87 banks operating in the USA covering the years 1999-2016. In the empirical findings obtained from the analyzes, it has been seen that the effect of gender diversity of the board of directors on the financial performance of the banks is not linear and the high number of women on the boards of directors has a positive effect on the financial performance. It is possible to summarize the above-mentioned field studies in general as follows: In the studies conducted by domestic researchers on gender diversity in the board of directors, the presence of women in the board of directors and the ratio of women, and the presence of women in the board of directors abroad, the rate of women, the presence of at least 1 woman, and the presence of 2 or more women are taken as independent variables. ROE, ROA and Tobin's q were taken as dependent variables.

In our study, presence of women in the board of directors, ratio of women, presence of at least 1 woman, presence of at least 2 or more women, and absence of at least 3 or more women were taken as independent variables. Both traditional (ROA and ROE) and value-oriented (EVA and MVA) financial performance measures were taken as the dependent variable. It is possible to say that this differentiates our research from previous empirical studies (especially domestic) and will contribute significantly to the field literature.

\section{DATASET, HYPOTHESES AND METHOD}

This study includes companies in the manufacturing sector that took part in the BIST continuously between 2010 and 2017. The research consists of 8,064 data observations in total ( 8 years) for our final sample, 126 unique firms. The data of the variables used in the study were obtained from the Finnet (www.finnet.com.tr), the Central Bank of the Republic of Turkey and the official website of the Public Disclosure Platform (PDP). Table 1 lists the variables used in the study and their explanations. 
Table 1: Variables Used in the Study and Their Explanations

\begin{tabular}{|c|c|}
\hline Variable & Explanation \\
\hline Woman (\%) & Ratio of female executives in the board of directors \\
\hline Woman $>=1$ & $\begin{array}{l}\text { Dummy variable is } 1 \text { for companies with at least } 1 \\
\text { woman on the board; otherwise it is } 0 .\end{array}$ \\
\hline Woman $>=2$ & $\begin{array}{l}\text { Dummy variable is } 1 \text { for companies with } 2 \text { or } \\
\text { more women on the board of directors; otherwise } \\
\text { it is } 0 \text {. }\end{array}$ \\
\hline Woman $>=3$ & $\begin{array}{l}\text { Dummy variable is } 1 \text { for companies with } 3 \text { or } \\
\text { more women on the board of directors; otherwise } \\
\text { it is } 0 \text {. }\end{array}$ \\
\hline Ln(Board Size) & Natural logarithm of board size \\
\hline Ln(Firm Size) & Natural logarithm of total assets \\
\hline Leverage & Ratio of total debt to total assets \\
\hline Return on Assets (ROA) & Ratio of period-end net profit to total assets \\
\hline Return on Equity (ROE) & Ratio of period-end net profit to total equity \\
\hline TA & Total Assets \\
\hline MVA/TA & $\begin{array}{l}\text { Ratio of Market Value Added to Total Assets } \\
\text { MVA= (Total Number of Shares in Circulation x } \\
\text { Share Closing Price) - Book Value of Equity) }\end{array}$ \\
\hline EVA/TA & $\begin{array}{l}\text { Ratio of Economic Value Added to Total Assets } \\
\text { [EVA= Operating Profit x (1-Corporate Tax Rate) } \\
\text { - (Invested Capital x Weighted Average Cost of } \\
\text { Capital)] } \\
\text { The EVA performance measure was calculated } \\
\text { according to the method used by Horasan and } \\
\text { Y1lmaz (2019) in their studies. }\end{array}$ \\
\hline
\end{tabular}

The independent variable, dummy variable, control variable and dependent variables used in the study are as follows: 


$\begin{aligned} \text { Independent variable } & =\text { Woman } \% \\ \text { Dummy variable } & =\text { Woman }>=1 \\ & =\text { Woman }>=2 \\ & =\text { Woman }>=3 \\ \text { Control variable } & =\text { Ln(Board size) } \\ & =\text { Ln(Firm size) } \\ & =\text { Leverage } \\ \text { Dependent variable } & =\text { ROA } \\ & =\text { ROE } \\ & =\text { MVA } / \mathrm{TA} \\ & =\text { EVA } / \text { TA }\end{aligned}$
as follows:

Based on the above data, the hypotheses of the research were established

$\mathbf{H}_{\mathbf{0}}=$ The effect of the presence of women on the company's board of directors on profit and added value is not significant.

$\mathbf{H}_{1}=$ The effect of the presence of women on the company's board of directors on profit and added value is significant.

In the study, some descriptive statistics of the variables were primarily included. Then, whether the independent variable and dummy variables have an effect on the dependent variables were tested with the regression analysis method in order to test the hypotheses established above. As can be seen in Table 1, the calculated MVA and EVA values of the companies were divided by Total Assets (TA-Total Assets) and their standardized values were used in the regression analysis.

\section{FINDINGS}

\subsection{Descriptive Statistics}

In this part of the study, the distribution of female members in the board of directors of companies by years and descriptive statistics about the dependent variable, independent variable, dummy variable and control variable in the research are included. The values of the number of female members and company distribution are given in Table 2. 
KAUJEASF 12(24), 2021: 781-809

Table 2: Number of Female Members and Distribution by Number of Companies

\begin{tabular}{|c|c|c|c|c|c|c|c|c|}
\hline \multirow{2}{*}{ Year } & \multirow{2}{*}{$\begin{array}{c}\text { Firm } \\
\text { Distribution }\end{array}$} & \multicolumn{7}{|c|}{ Number of Female Members } \\
\hline & & $\mathbf{0}$ & 1 & 2 & 3 & 4 & 5 & 6 \\
\hline \multirow[b]{2}{*}{2010} & $\mathrm{~N}$ & 61 & 34 & 17 & 10 & 4 & $\overline{0}$ & 0 \\
\hline & $\%$ & 48.41 & 26.98 & 13.49 & 7.94 & 3.17 & 0.00 & 0,00 \\
\hline \multirow{2}{*}{2011} & $\mathrm{~N}$ & 58 & 34 & 19 & 11 & 3 & 0 & 1 \\
\hline & $\%$ & 46.03 & 26.98 & & 8.73 & 2.38 & 0.00 & 0.79 \\
\hline \multirow{2}{*}{2012} & $\mathrm{~N}$ & 53 & 45 & 16 & 10 & 1 & 1 & 0 \\
\hline & $\%$ & 42.06 & 35.71 & 12.70 & 7.94 & 0.79 & 0.79 & 0.00 \\
\hline \multirow{2}{*}{2013} & $\mathrm{~N}$ & 57 & 47 & 13 & 8 & 1 & 0 & 0 \\
\hline & $\%$ & 45.24 & 37.30 & 10.32 & 6.35 & 0.79 & 0.00 & 0.00 \\
\hline \multirow{2}{*}{2014} & $\mathrm{~N}$ & 54 & 44 & 21 & 7 & 0 & 0 & 0 \\
\hline & $\%$ & 42.86 & 34.92 & 16.67 & 5.56 & 0.00 & 0.00 & 0.00 \\
\hline \multirow{2}{*}{2015} & $\mathrm{~N}$ & 54 & 44 & 21 & 7 & 0 & 0 & 0 \\
\hline & $\%$ & 42.86 & 34.92 & 16.67 & 5.56 & 0.00 & 0.00 & 0.00 \\
\hline \multirow{2}{*}{2016} & $\mathrm{~N}$ & 53 & 40 & 21 & 11 & 1 & 0 & 0 \\
\hline & $\%$ & 42.06 & 31.75 & 16.67 & 8.73 & 0.79 & 0.00 & 0.00 \\
\hline \multirow{4}{*}{2017} & $\mathrm{~N}$ & 56 & 36 & 24 & 10 & 0 & 0 & 0 \\
\hline & $\%$ & 44.44 & 28.57 & 19.05 & 7.94 & 0.00 & 0.00 & 0.00 \\
\hline & Total & 446 & 324 & 152 & 74 & 10 & 1 & 1 \\
\hline & $\%$ & 44.25 & 32.14 & 15.08 & 7.34 & 0.99 & 0.10 & 0.10 \\
\hline
\end{tabular}

According to the results in Table 2, it was determined that $44.25 \%$ of the companies did not have any women on the board of directors during the 20102017 review period. It was observed that $32.14 \%$ of the companies have 1 woman, $15.08 \%$ of the companies have 2 women, $7.34 \%$ of the companies have 3 women, $0.99 \%$ of the companies have 4 women, and $0.10 \%$ have 5 and 6 women. In addition, it is seen that the period in which the enterprises that do not have any women on the board of directors were the highest in $2010(48.41 \%)$ and the least in $2012(42.06 \%)$. Based on this result, it is possible to say that BIST manufacturing companies keep the participation of female managers in the board of directors where strategic decisions are taken at a low level. Figure 1 gives the total number of women on the board of directors of 126 companies by years. 
Figure 1: Total Number of Women in the Board of Directors by Years

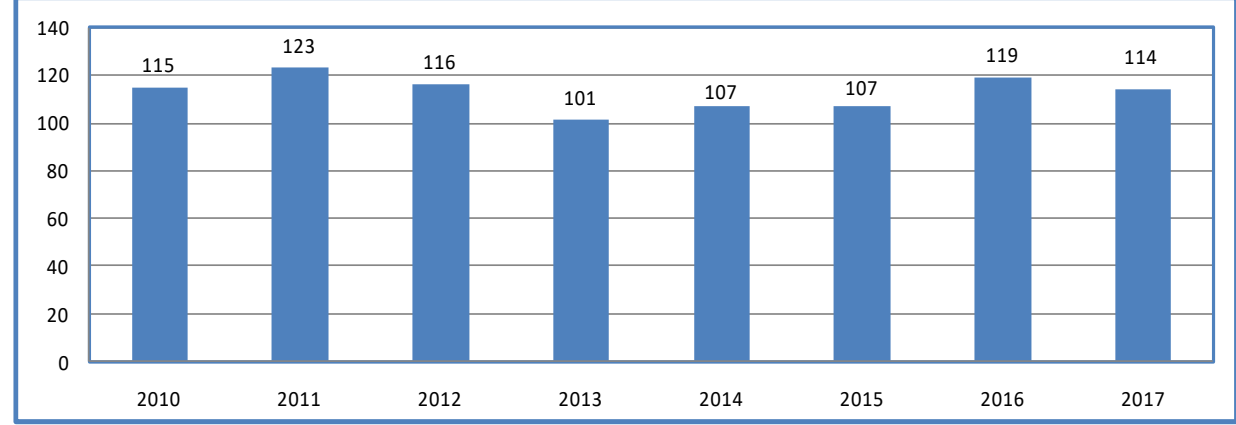

As seen in Figure 1, 2011 was the year in which 126 different companies had the highest number of female members on the board of directors. It is followed by 2016, 2012, 2010, 2014 and 2015, 2017 and 2013, respectively. The annual average of female members per company was calculated as 0.91 in 2010, 0.98 in 2011, 0.92 in 2012, 0.80 in 2013, 0.85 in 2014 and 2015, 0.94 in 2016, and 0.91 in 2017 . The average values of the ratio of female members in the boards of directors of companies in the period of 2010-2017 are as in Figure 2.

Figure 2: Proportion of Female Members

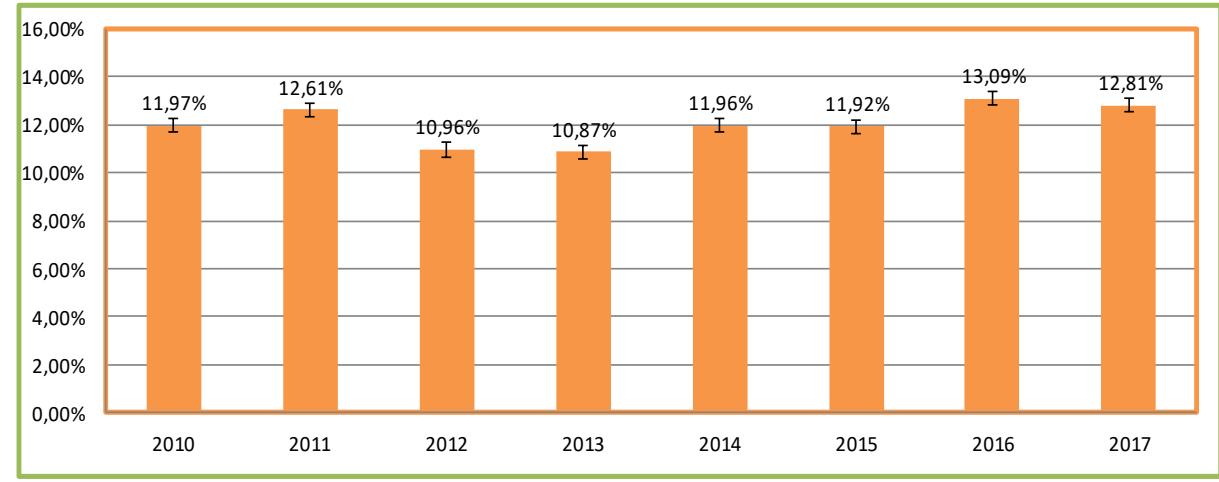

When Figure 2 is examined, the average rate of female members on the board of directors of companies was the highest in 2016, followed by 2017, 2011, 2010, 2014, 2015, 2012 and 2013, respectively. During the 8-year review period, the average of female members was $12.02 \%$. 
The results of the descriptive statistics of the variables used in the analysis part of the study are also presented in Table 2 .

Table 2: Summary Statistics of the Variables Included in the Analyzes

\begin{tabular}{lccccc}
\hline Variable & $\mathrm{N}$ & Minimum & Maximum & Mean & Standard Deviation \\
\hline Number of women & 1008 & 0 & 6 & 0.895 & 1.003 \\
Board size & 1008 & 3 & 15 & 7.731 & 2.431 \\
Woman \% & 1008 & 0.000 & 0.750 & 0.120 & 0.140 \\
ROE & 1008 & -1.857 & 0.861 & 0.050 & 0.228 \\
ROA & 1008 & -0.541 & 0.372 & 0.035 & 0.086 \\
MVA/TA & 1008 & -0.899 & 3.125 & 0.246 & 0.532 \\
EVA/TA & 1008 & -2.783 & 3.052 & 0.024 & 0.568 \\
Firm size & 1008 & 14.853 & 24.365 & 19.696 & 1.613 \\
Leverage & 1008 & 0.0497 & 1.708 & 0.498 & 0.224 \\
\hline
\end{tabular}

According to the average values reported in Table 2, the number of female members per company in the 8 -year period was 0.895 , the size of the board of directors was 7.731 , and the rate of female members was $12 \%$. When the average financial values of the companies are examined, it has been determined that the ROE ratio is $5 \%$, the ROA ratio is $3.5 \%$, the MVA/TA ratio is $24.6 \%$, the EVA/TA ratio is $2.4 \%$, the firm size is 19.969 , and the debt leverage ratio is $49.8 \%$.

\subsection{T-Test Results}

Table 3 shows the means of the values, the difference between the means, the $t$ statistical value, and the p probability values showing whether this is significant or not, for the companies with and without female directors on the board of directors in the 2010-2017 period.

Table 3: Comparison of Companies with and Without Women on the Board of

\begin{tabular}{llllll}
\multicolumn{5}{c}{ Directors } \\
\hline Variable & $\begin{array}{l}\text { Mean of } \\
\text { companies with } \\
\text { no women on the } \\
\text { board }\end{array}$ & $\begin{array}{l}\text { Mean of } \\
\text { companies } \\
\text { with women on } \\
\text { the board }\end{array}$ & $\begin{array}{c}\text { Mean } \\
\text { difference }\end{array}$ & $\begin{array}{c}\mathrm{t} \\
\text { value }\end{array}$ & $\begin{array}{c}\mathrm{p} \\
\text { value }\end{array}$ \\
\hline $\mathrm{N}$ & 445 & 563 & & & \\
Board size & 1.955 & 2.032 & -0.077 & -4.026 & $0.000^{* * * *}$ \\
ROE & 0.048 & 0.051 & -0.003 & -0.210 & 0.834 \\
ROA & 0.028 & 0.040 & -0.012 & -2.303 & $0.022^{* *}$ \\
MVA/TA & 0.247 & 0.246 & 0.001 & 0.028 & 0.978 \\
EVA/TA & 0.022 & 0.025 & -0.004 & -0.105 & 0.916 \\
Firm size & 19.551 & 19.811 & -0.261 & -2.554 & $0.011^{* *}$ \\
Leverage & 0.507 & 0.490 & 0.017 & 1.198 & 0.231 \\
\hline
\end{tabular}

The symbols ***,**, * indicate significance at the $1 \%, 5 \%$ and $10 \%$ level. The explanations of the variables are presented in Table 1 . 
In Table 3, the Independent Sample T-Test was used to determine the difference between the values of companies with and without women on the board of directors and to determine the significance of this difference. The average values obtained according to the status of being or not a woman in the board of directors in Table 3 and the p statistical results representing the significance level of the difference between these values are interpreted as follows.

The difference between the mean size of the board of directors of companies that do not have women on the board of directors and those with women on the board of directors was found to be $1 \%(t=-4.026, p=0.000)$. The difference between the ROA mean was $5 \%(\mathrm{t}=-2.303, \mathrm{p}=0.022)$, and the difference between the asset size mean was $5 \%(\mathrm{t}=-2.303 ; \mathrm{p}=0.022)$. In other variables, the difference between the mean values was not significant at any level. These comparisons show us that the choice of companies to nominate talented female executives may be affected by the characteristics of the firm, that the share of female executives on the board of directors of large firms is more pronounced than that of small firms, and that the average ROA and board size of firms with women on the board are higher and more significant.

\subsection{Multiple Regression Analysis Results}

Multiple regression analysis was used to test whether the proportion of women in the board of directors, the presence of women, and the presence of 2 or more women managers have an effect on firm performance. Our multiple regression model is set up as follows.

$$
\left(\text { firm performance }_{i t}\right)=\beta_{0}+\beta_{1} \text { woman }_{i t}+\beta_{2} \text { control variables }_{i t}+\mu_{i t}
$$

In the model, $i$ represents the firm, $\mathrm{t}$ time, $\beta_{0}$ represents the constant coefficient, $\beta_{1}$ represents the coefficient of the independent variable, $\beta_{2}$ represents the coefficient of the control variable, and $\mu$ represents the error term. ROE, ROA, MVA/TA and EVA/TA company performance, percentage of women on the board ( $\%$ female members), having at least 1 , at least 2 and at least 3 and more women (puppet women), board size and company size are included in the model as a control variable. The statistical results of 16 different multiple regression models analyzed with the linear method are presented in Table 4, Table 5, Table 6 and Table 7. 
KAUJEASF 12(24), 2021: 781-809

Table 4: Company Performance Analysis by Percentage of Women in the Board of Directors (\%)

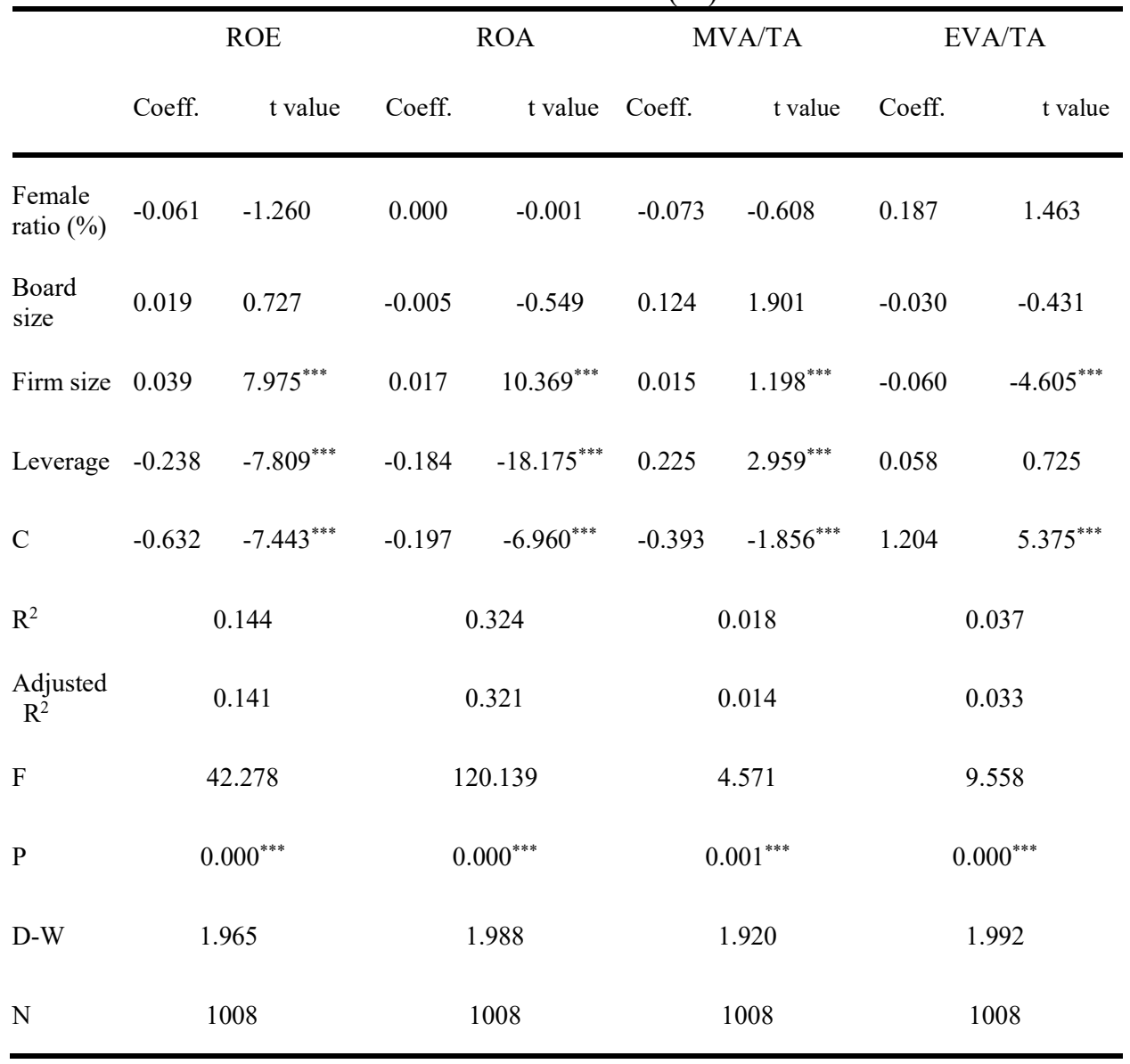

The symbols ***,**,* indicate significance at the $1 \%, 5 \%$ and $10 \%$ level. The explanations of the variables are presented in Table 1 .

According to Table 4, which includes the statistical values obtained from the analysis results of the effect of the ratio of women in the board of directors of 126 companies on the financial performance variables in the 2010-2017 period, the effect was not significant. In other words, we concluded that the rate of women in the company's board of directors did not affect the profit and value added variables within the scope of the analysis. Independent variables explain ROE as $14.4 \%$, ROA as $32.4 \%$, MVA/TA as $1.8 \%$, and EVA/TA as $3.7 \%$. 
Table 5: Company Performance Analysis with At least 1 Female Member in the Board of Directors

\begin{tabular}{|c|c|c|c|c|c|c|c|c|}
\hline & \multicolumn{2}{|c|}{ ROE } & \multicolumn{2}{|c|}{ ROA } & \multicolumn{2}{|c|}{ MVA/TA } & \multicolumn{2}{|c|}{ EVA/TA } \\
\hline & Coeff. & $\mathrm{t}$ value & Coeff. & $\mathrm{t}$ value & Coeff. & $\mathrm{t}$ value & Coeff. & $\mathrm{t}$ value \\
\hline Women $>=1$ & -0.013 & -0.970 & 0.005 & 1.196 & -0.011 & -0.326 & 0.024 & 0.665 \\
\hline Board size & 0.023 & 0.863 & -0.006 & -0.659 & 0.128 & $1.948^{*}$ & -0.038 & -0.547 \\
\hline Firm size & 0.040 & $8.156^{* * *}$ & 0.017 & $10.403^{* * *}$ & 0.015 & 1.270 & -0.062 & $-4.782^{* * *}$ \\
\hline Leverage & -0.239 & $-7.829^{* * *}$ & -0.184 & $-18.162^{* * *}$ & 0.224 & $2.950^{* * *}$ & 0.060 & 0.743 \\
\hline $\mathrm{C}$ & -0.652 & $-7.851^{* * *}$ & -0.197 & $-7.131^{* * *}$ & -0.418 & $-2.018^{* *}$ & 1.270 & $5.783^{* * *}$ \\
\hline $\mathrm{R}^{2}$ & \multicolumn{2}{|c|}{0.144} & \multicolumn{2}{|c|}{0.325} & \multicolumn{2}{|c|}{0.018} & \multicolumn{2}{|c|}{0.035} \\
\hline Adjusted $\mathrm{R}^{2}$ & \multicolumn{2}{|c|}{0.140} & \multicolumn{2}{|c|}{0.322} & \multicolumn{2}{|c|}{0.014} & \multicolumn{2}{|c|}{0.031} \\
\hline $\mathrm{F}$ & \multicolumn{2}{|c|}{42.089} & \multicolumn{2}{|c|}{120.668} & \multicolumn{2}{|c|}{4.504} & \multicolumn{2}{|c|}{9.118} \\
\hline $\mathrm{P}$ & \multicolumn{2}{|c|}{$0.000^{* * *}$} & \multicolumn{2}{|c|}{$0.000^{* * *}$} & \multicolumn{2}{|c|}{$0.001^{* * *}$} & \multicolumn{2}{|c|}{$0.000^{* * *}$} \\
\hline D-W & \multicolumn{2}{|c|}{1.965} & \multicolumn{2}{|c|}{1.991} & \multicolumn{2}{|c|}{1.919} & \multicolumn{2}{|c|}{1.989} \\
\hline $\mathrm{N}$ & \multicolumn{2}{|c|}{1008} & \multicolumn{2}{|c|}{1008} & \multicolumn{2}{|c|}{1008} & \multicolumn{2}{|c|}{1008} \\
\hline
\end{tabular}

The symbols $* * *, * *, *$ indicate significance at the $1 \%, 5 \%$ and $10 \%$ level. The explanations of the variables are presented in Table 1 .

Table 5 shows the results of the regression analysis regarding the effect of having 1 or more women on the board of directors of companies on financial performance indicators. As can be seen in the table, it has been observed that having 1 or more women on the board of directors has no effect on the financial indicators taken as the dependent variable. Independent variables explain ROE $14.4 \%$, ROA $32.5 \%$, MVA/TA $1.8 \%$, EVA/TA $3.5 \%$. 
Table 6: Company Performance Analysis with At least 2 Female Members in the Board of Directors

\begin{tabular}{|c|c|c|c|c|c|c|c|c|}
\hline & \multicolumn{2}{|c|}{ ROE } & \multicolumn{2}{|r|}{$\mathrm{ROA}$} & \multicolumn{2}{|c|}{ MVA/TA } & \multicolumn{2}{|c|}{ EVA/TA } \\
\hline & Coeff. & $\mathrm{t}$ value & Coeff. & $\mathrm{t}$ value & Coeff. & $\mathrm{t}$ value & Coeff. & $\mathrm{t}$ value \\
\hline Women $>=2$ & -0.031 & $-1.949^{*}$ & -0.006 & -1.072 & -0.037 & -0.934 & 0.029 & 0.686 \\
\hline Board size & 0.031 & 1.150 & -0.003 & -0.328 & 0.142 & $2.131^{* *}$ & -0.044 & -0.623 \\
\hline Firm size & 0.038 & $7.653^{* * *}$ & 0.017 & $10.056^{* * *}$ & 0.013 & 1.042 & -0.060 & $-4.560^{* * *}$ \\
\hline Leverage & -0.238 & $-7.825^{* * *}$ & -0.184 & $-18.184^{* * *}$ & 0.226 & $2.969^{* * *}$ & 0.059 & 0.730 \\
\hline $\mathrm{C}$ & -0.632 & $-7.543^{* * *}$ & -0.192 & $-6.904^{* * *}$ & -0.394 & $-1.886^{*}$ & 1.251 & $5.648^{* * *}$ \\
\hline $\mathrm{R}^{2}$ & \multicolumn{2}{|c|}{0.146} & \multicolumn{2}{|r|}{0.325} & \multicolumn{2}{|c|}{0.019} & \multicolumn{2}{|c|}{0.035} \\
\hline Adjusted $\mathrm{R}^{2}$ & \multicolumn{2}{|c|}{0.143} & \multicolumn{2}{|r|}{0.322} & \multicolumn{2}{|c|}{0.015} & \multicolumn{2}{|c|}{0.031} \\
\hline $\mathrm{F}$ & \multicolumn{2}{|c|}{42.928} & \multicolumn{2}{|c|}{120.562} & \multicolumn{2}{|c|}{4.760} & \multicolumn{2}{|c|}{9.128} \\
\hline $\mathrm{P}$ & \multicolumn{2}{|c|}{$0.000^{* * *}$} & \multicolumn{2}{|c|}{$0.000^{* * *}$} & \multicolumn{2}{|c|}{$0.001^{* * *}$} & \multicolumn{2}{|c|}{$0.000^{* * *}$} \\
\hline D-W & \multicolumn{2}{|c|}{1.964} & \multicolumn{2}{|r|}{1.985} & \multicolumn{2}{|c|}{1.920} & \multicolumn{2}{|c|}{1.989} \\
\hline $\mathrm{N}$ & \multicolumn{2}{|c|}{1008} & \multicolumn{2}{|r|}{1008} & \multicolumn{2}{|c|}{1008} & \multicolumn{2}{|c|}{1008} \\
\hline
\end{tabular}

The symbols $* * *, * *, *$ indicate significance at the $1 \%, 5 \%$ and $10 \%$ level. The explanations of the variables are presented in Table 1 .

According to Table 6, which includes the findings obtained in the regression analysis conducted to examine the effect of having at least 2 female members in the board of directors on company performance, only the effect on ROE was significant $(t=-1.949, \mathrm{p}=0.000)$, while the effect on other performance variables was not significant. Independent variables explain ROE as $14.6 \%$, ROA as $32.5 \%$, MVA/TA as $1.9 \%$, and EVA/TA as $3.5 \%$. 
Table 7: Firm Performance Analysis in the Condition of Having At least 3 Female Members in the Board of Directors

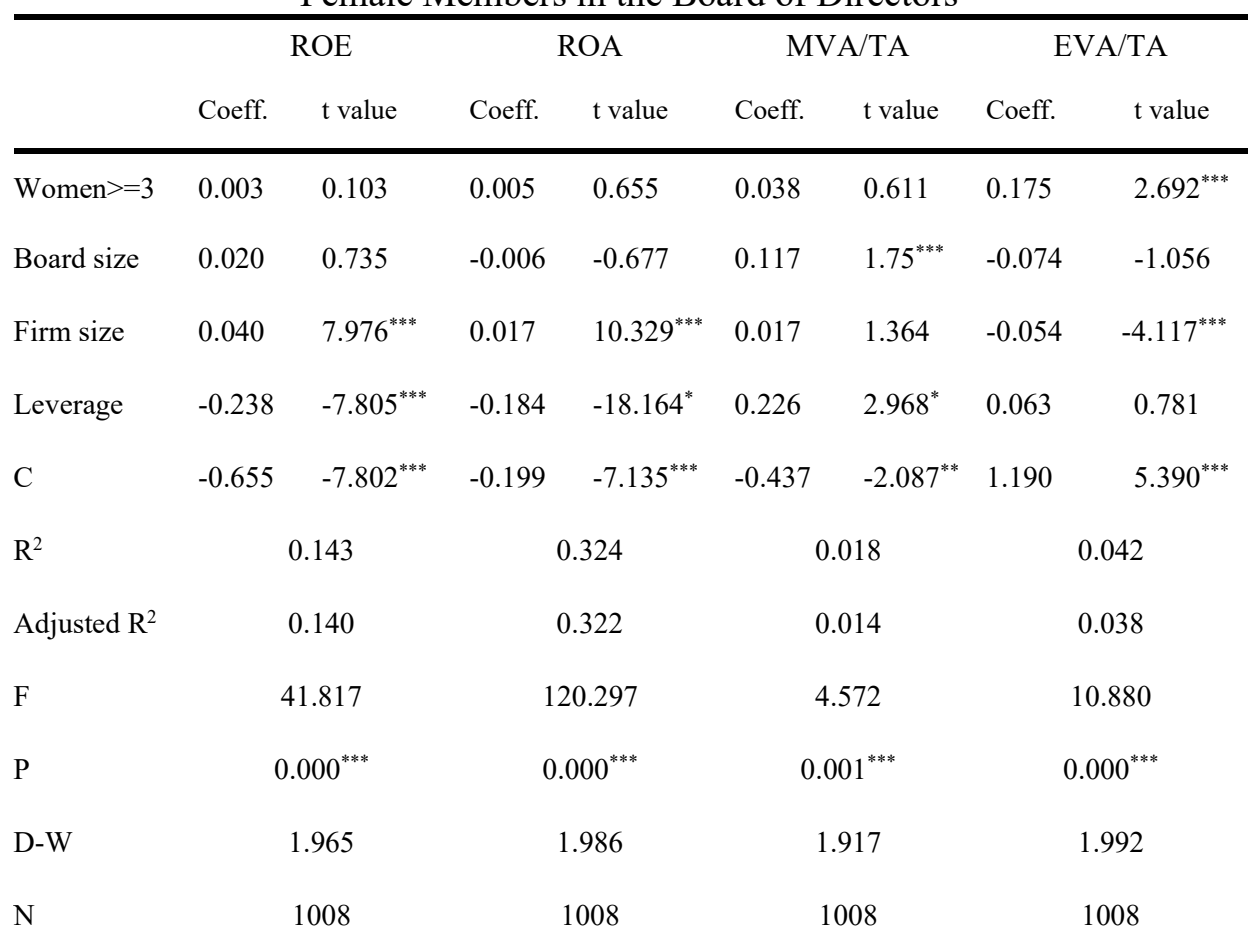

The symbols $* * *, * *, *$ indicate significance at the $1 \%, 5 \%$ and $10 \%$ level. The explanations of the variables are presented in Table 1 .

According to the findings in Table 7, which includes the results of the regression analysis conducted to test the effect of having 3 or more women on the board of directors of the companies, on the financial performance, only the effect on EVA/TA was found to be significant at the $1 \%$ level $(\mathrm{t}=2.692, \mathrm{p}=0.000)$, the effect on other variables was not significant. In addition, $14.6 \%$ of ROE, $32.5 \%$ of ROA, $1.9 \%$ of MVA/TA, 3.5\% of EVA/TA were explained by independent variables.

The $\mathrm{p}$ values in Table 4, Table 5, Table 6 and Table 7, which include the results of multiple regression analysis, were less than 0.05 , indicating that the multiple regression models are significant as a whole. Durbin-Watson (D-W) test statistical values were between 1.917 and 1.992 , indicating that there is no autocorrelation in the established models. 


\section{CONCLUSION}

Boards of directors are the center where more than one senior executives come together and manage the corporate decision-making processes of the enterprises. Therefore, the members of the board of directors play a key role in the final decision-making processes of the company's plans, policies and strategic activities. There is an increasing focus on gender diversity among members who actively participate in decisions taken by the board of directors, which represents the center of corporate governance components.

In recent years, many arrangements have been made around the world aimed at increasing the representation of women on company boards; because the issue of representation of women members on company boards of directors is also of great interest to industry representatives, policy makers and researchers. In addition, ensuring greater gender diversity in the company's board, where corporate decisions are made, is also a prominent consideration in the current governance arrangements. It is based on the idea that suggestions and regulations to increase the ratio of female managers in the boards of directors will be beneficial both for increasing women's employment and for company performance. However, we cannot say that a consensus has been reached on the benefits of diversifying the board of directors by appointing a female executive to the boards, which affect all the governance mechanisms of the company with the decisions taken.

In this study, we investigate the economic role of female executives on the company's boards of companies operating in a traditional cultural society dominated by men, still exhibiting strong resistance to gender equality, and where it is difficult for talented female executives to participate in company senior management. In the findings obtained in our analyzes, we could not find any evidence that women's representation on the board of directors has an economically significant effect on firm performance in general. However, it was observed that women $>=2$ in the board of directors had a low negative effect on ROE, and female $>=3$ had a positive and low significant effect on EVA/TA. These results provide us with meaningful evidence that more female representation on the board reduces ROE and increases the EVA/TA ratio. In other financial variables, the evidence for the effects of the presence of female managers on profit and value added was not significant. According to these findings, Wang and Clift (2009), Karayel and Doğan (2014), Low et al. (2015), Chauhan and Dey (2017), At1lgan (2017) studies were found to overlap with the results of the study. In contrast, the studies of Adams and Ferreira (2009), Darmadi (2010), Julizaerma and Sori (2012), January (2013), García et al. (2015), 
Otluoglu et al. (2016), Wiengarten et al. (2017), Ghosh and Ansari (2018), Green and Homroy (2018), Owen and Temesvary (2018) were found to be inconsistent with the findings of this study.

As a result, the limitations of the study include the reasons such as the fact that this study covers only a certain sector, there is a certain time period, certain companies are included in the research, and companies operate in a developing country where male dominance is dominant. For these reasons, we cannot say that the recruitment of talented female managers who want to make a career in company management mechanisms will not be beneficial in terms of company performance in general. Findings from other studies to be conducted for countries with different time periods, different sectors and institutional arrangements on whether gender diversity improves firm performance may differ from our results. While companies bring a heterogeneous distribution by diversifying the board of directors, attention should be paid to the integration, cost and promotion policies between male and female managers within the organization. Finally, we hope that the results of this research will encourage more extensive and more research in the future into whether the actual impact of female executives on companies' earnings management is positive.

\section{DECLARATION OF CONFLICT OF INTEREST}

There is no conflict of interest between the authors.

\section{FINANCIAL SUPPORT}

No funding or support was used in this study.

\section{AUTHOR CONTRIBUTIONS}

TY, AA, and YZ: Opinion;

TY and AA: Design;

TY: Supervision;

TY, AA and YZ: Collection and/or processing of resources;

TY and YZ: Analysis and/or comment;

AA and YZ: Literature review;

TY, AA, and YZ: The people who wrote the article;

TY and YZ: Critical review 


\section{ETHICS COMMITTEE STATEMENT AND INTELLECTUAL PROPERTY COPYRIGHTS}

Ethics committee principles were complied with in the study and necessary permissions were obtained in accordance with the intellectual property and copyright principles.

\section{REFERENCES}

Adams, R. B., \& Ferreira, D. (2009). Women in the boardroom and their impact on governance and performance. Journal of Financial Economics, 94(2), 291-309.

Akpinar Sposito, C. (2013). Career barriers for women executives and the glass ceiling syndrome: The case study comparison between French and Turkish women executives. Procedia-Social and Behavioral Sciences, 75, 488-497.

Aktan, C. C. (2013). Kurumsal şirket yönetimi. Organizasyon Ve Yönetim Bilimleri Dergisi, 5(1), 150-161.

Anderson, R. C., \& Reeb, D. M. (2004). Board composition: Balancing family influence in S\&P 500 firms. Administrative Science Quarterly, 49(2), 209-237.

Arioglu, E. (2014). Demographic diversity in the boardroom: Evidence from Borsa İstanbul. Research Journal of Business and Management, 2(1), 18-36.

Arosa, B., Iturralde, T. \& Maseda, A. (2010). Outsiders on the board of directors and firm performance: Evidence from Spanish non-listed family firms. Journal of Family Business Strategy, 1(4), 236-245.

Arslantaş, C.C. (2012). Kurumsal yönetimin yönetim kuruluna yansımaları (1.b). İstanbul: Beta Yayıncilik.

Aslantaş, M.F., \& Yılmaz, T. (2020). Finansal performans araştırmalarında güncel yaklaşımlar. B. Güngör ve C. Yerdelen Kaygın (Ed.). Covid-19 döneminde kamu sermayeli mevduat bankalarının finansal performansları üzerine bir inceleme (327-349). Ankara: Nobel Yayınc1lik.

Atılgan, Ö. (2017). Yönetim kurulu büyüklüğü, bağımsız üye oranı ve kadın üye oranı ile finansal performans ilişkisi. Dokuz Eylül Üniversitesi İktisadi ve İdari Bilimler Fakültesi Dergisi, 32(2), 315-354.

Balasubramanian, B.N., \& Anand, R.V. (2013). Ownership trends in corporate India 20012011: Evidence and implications. IIM Bangalore Research Paper No. 419, 1-91.

Buallay, A., Hamdan, R., Barone, E., \& Hamdan, A. (2020). Increasing female participation on boards: Effects on sustainability reporting. International J Fin \& Econ, 1-14.

Çalışkan A. (2017). Yönetim ve strateji 101 teori ve yaklaşım. Ömer Turunç ve Hakan Turgut (Ed.). Kaynak bağımlılı̆̆ı teorisi (221-269). Ankara: Siyasal Kitabevi. 
Campbell, K., \& Vera, A. M. (2010). Female board appointments and firm valuation: Short and long-term effects. Journal of Management \& Governance, 14(1), 37-59.

Carter, D. A., D’Souza, F., Simkins, B. J., \& Simpson, W. G. (2010). The gender and ethnic diversity of us boards and board committees and firm financial performance. Corporate Governance: An International Review, 18(5), 396-414.

Chapple, L., \& Humphrey, J. E. (2014). Does board gender diversity have a financial impact? Evidence using stock portfolio performance. Journal of Business Ethics, 122(4), 709-723.

Chauhan, Y., \& Dey, D. K. (2017). Do female directors really add value in Indian firms?. Journal of Multinational Financial Management, 42, 24-36.

Conyon, M. J., \& He, L. (2017). Firm performance and boardroom gender diversity: A quantile regression approach. Journal of Business Research, 79, 198-211.

Dargnies, M.P. (2012). Men too sometimes shy away from competition: The case of team competition. Management Science, 58(11), 1982-2000.

Darmadi S. (2010). Board diversity and firm performance: The Indonesian evidence. Corporate Ownership and Control Journal, 8, 1627-1637.

De Andres, P., Azofra, V., \& Lopez, F. (2005). Corporate boards in OECD countries: Size, composition, functioning and effectiveness. Corporate governance: $A n$ International Review, 13(2), 197-210.

Doğan, M. (2018). Kadın yönetim kurulu üye sayısının finansal performans üzerinde etkisi: Literatür taraması. Uluslararası Yönetim Akademisi Dergisi, 1(2), 132-141.

Ertimur, Y., Ferri, F., \& Stubben, S. R. (2010). Board of directors' responsiveness to shareholders: Evidence from shareholder proposals. Journal of Corporate Finance, 16(1), 53-72.

Farrell, K. A., \& Hersch, P. L. (2005). Additions to corporate boards: The effect of gender. Journal of Corporate Finance, 11(1-2), 85-106.

Francoeur, C., Labelle, R., \& Sinclair-Desgagné, B., (2008). Gender diversity in corporate governance and top management. Journal of Business Ethics, 81(1), 83-95.

García Meca, E., García-Sánchez, I. M., \& Martínez-Ferrero, J. (2015). Board diversity and its effects on bank performance: An international analysis. Journal of Banking \& Finance, 53, 202-214.

Ghosh, S., \& Ansari, J. (2018). Board characteristics and financial performance: Evidence from Indian cooperative banks. Journal of Co-operative Organization and Management, 6(2), 86-93.

Green, C. P., \& Homroy, S. (2018). Female directors, board committees and firm performance. European Economic Review, 102, 19-38. 
Hillman, A. J., Cannella, A. A., \& Paetzold, R. L. (2000). The resource dependence role of corporate directors: Strategic adaptation of board composition in response to environmental change. Journal of Management studies, 37(2), 235-256.

Horasan, E. \& Yılmaz, T. (2019). Türk imalat şirketlerinde piyasa katma değerini (mva) açıklayan ekonomik katma değer (EVA) mi yoksa kârlılık mı?. Balıkesir Üniversitesi Sosyal Bilimler Enstitüsü Dergisi, 22(41), 295-315.

Hsu H.H, \& Wu C.Y.H. (2014). Board composition, grey directors and corporate failure in the UK. Br Account Rev, 46, 215-227.

Jermias, J., \& Gani, L. (2014). The impact of board capital and board characteristics on firm performance. The British Accounting Review, 46(2), 135-153.

Julizaerma, M. K., \& Sori, Z. M. (2012). Gender diversity in the boardroom and firm performance of Malaysian public listed companies. Procedia-Social and Behavioral Sciences, 65, 1077-1085.

Jurkus, A. F., Park, J. C., \& Woodard, L. S. (2011). Women in top management and agency costs. Journal of Business Research, 64(2), 180-186.

Kalkınma Bakanlığı (2018). Kadının kalkınmadaki rolü, on birinci kalkınma planı (20192023). Özel İhtisas Komisyonu Raporu. Ankara. https://www.sbb.gov.tr/wpcontent/uploads/2020/04/KadininKalkinmadakiRoluOzelIhtisasKomisyonuRapo ru.pdf.

Karabıyık, İ. (2015). Türkiye'de çalışma hayatında kadın istihdamı. Marmara Üniversitesi İktisadi ve İdari Bilimler Dergisi, 32(1), 231-260.

Karatepe, S., \& Arıbaş, N. (2015). İş hayatında kadın yöneticilere ilişkin cinsiyet ayrımcılığı: Türkiye için bir değerlendirme. Yasama Dergisi, 31, 7-23.

Karayel M., \& Doğan M. (2014), Yönetim kurulunda cinsiyet çeşitliliği ve finansal performans ilişkisi: BIST 100 şirketlerinde bir araştırma. Süleyman Demirel Üniversitesi İktisadi ve İdari Bilimler Fakültesi Dergisi, 19(2), 75-88.

Kolade, O. J., \& Kehinde, O. (2013). Glass ceiling and women career advancement: Evidence from Nigerian construction industry. Iranian Journal of Management Studies (IJMS), 6(1), 77-97.

Kouaib, A., Mhiri, S., \& Jarboui, A. (2020). Board of directors' effectiveness and sustainable performance: The triple bottom line. The Journal of High Technology Management Research, 31(2), 1-11.

Lanis, R., \& Richardson, G. (2011). The effect of board of director composition on corporate tax aggressiveness. Journal of Accounting and Public Policy, 30(1), 5070 . 
Liu, Y., Wei, Z., \& Xie, F. (2014). Do women directors improve firm performance in China? Journal of Corporate Finance, 28, 169-184.

Low, D. C., Roberts, H., \& Whiting, R. H. (2015). Board gender diversity and firm performance: Empirical evidence from Hong Kong, South Korea, Malaysia and Singapore. Pacific-Basin Finance Journal, 35, 381-401.

Meydan C. H. \& Basım, H. N. (2007). Kurumsal yönetim-şirket performansı ilişkisi: kuramsal bir analiz. Kara Harp Okulu Savunma Bilimleri Dergisi, 6(2), 48-67.

Mordi, C., Adedoyin, H., \& Ajonbadi, H. (2011). Impediments to women career advancement: The Nigerian experience. Petroleum-Gas University of Ploiesti: Bulletin, Economic Sciences Series, 43(2), 11-22.

Ocak, M. (2013). Yönetim kurulu ve üst yönetimde yer alan kadınların finansal performansa etkisi: Türkiye'ye ilişkin bulgular. Muhasebe ve Finansman Dergisi, $60,107-126$.

Otluoglu, E., Sari, E., \& Cakmak, K. O. (2016). Yönetim kurulu çeşitliliğinin finansal performansa etkisi: BIST 100 üzerine bir araştırma. Uluslararası Sosyal Araştırmalar Dergisi, 9(46), 749-758.

Owen, A. L., \& Temesvary, J. (2018). The performance effects of gender diversity on bank boards. Journal of Banking \& Finance, 90, 50-63.

Özen, A.K. ve Yılmaz, T. (2016). Bağımlı ve bağımsız yönetim kurulu üyelerinin işletmenin finansal performansına etkisi. Akademik Bakış Uluslararası Hakemli Sosyal Bilimler Dergisi, 58, 455-471.

Post, C., \& Byron, K. (2015). Women on boards and firm financial performance: A metaanalysis. Academy of Management Journal, 58(5), 1546-1571.

Pucheta Martínez, M. C., \& Gallego Álvarez, I. (2020). Do board characteristics drive firm performance? An international perspective. Review of Managerial Science, 14(6), 1251-1297.

Rao, K. K., \& Tilt, C. (2020). Gender and CSR decisions: perspectives from Australian boards. Meditari Accountancy Research. 19(1), 60-85.

Şahin, K., Burçin, E., Kaplan, T., \& Özdündar, G. (2018). Yönetim kurullarında kadın yönetici temsili: Türkiye'de yönetim kurulları yapısının cinsiyet bağlamında incelenmesi. Uluslararası Yönetim İktisat ve İşletme Dergisi, 14(4), 1147-1166.

Shoham, A., Lee, S. M., Khan, Z., Tarba, S. Y., \& Ahammad, M. F. (2020). The effect of board gender diversity on cross-listing. Journal of Corporate Finance, 65, 1-31.

Smith, N., Smith, V., \& Verner, M. (2006). Do women in top management affect firm performance? A panel study of 2,500 Danish firms. International Journal of Productivity and Performance Management, 55, 569-593. 
Talavera, O., Yin, S., \& Zhang, M. (2018). Age diversity, directors' personal values, and bank performance. International Review of Financial Analysis, 55, 60-79.

Tasheva, S., \& Hillman, A. J. (2019). Integrating diversity at different levels: Multilevel human capital, social capital, and demographic diversity and their implications for team effectiveness. Academy of Management Review, 44(4), 746-765.

Triana, M. D. C., Miller, T. L., \& Trzebiatowski, T. M. (2014). The double-edged nature of board gender diversity: Diversity, firm performance, and the power of women directors as predictors of strategic change. Organization Science, 25(2), 609-632.

Tunç, A., Yurdanur U. U., \& Gökçe A.F. (2015). Türk kamu yönetiminde personel ve yönetici olarak kadının varlığı: Aile ve Sosyal Politikalar Bakanlığı örneği. KADAUM 1. Uluslararası Çukurova Kadın Çalışmaları Kongresi, 9-11 Nisan 2015 Adana.

Wang, Y., \& Clift, B. (2009). Is there a "business case" for board diversity? Pacific Accounting Review, 22(2), 88-103.

Wang, Y., Wilson, C., \& Li, Y. (2020). Gender attitudes and the effect of board gender diversity on corporate environmental responsibility. Emerging Markets Review, 117.

Wiengarten, F., Lo, C. K., \& Lam, J. Y. (2017). How does sustainability leadership affect firm performance? The choices associated with appointing a chief officer of corporate social responsibility. Journal of Business Ethics, 140(3), 477-493. 